\title{
Administrative Reforms in Swiss Municipalities over the Last Twenty Years - The end of New Public Management?
}

\author{
ANDREAS LADNER
}

\begin{abstract}
There has been much talk about the end the NPM in recent years. Our comprehensive monitoring of Swiss municipalities, however, reveals that a lot of municipalities have continued to reform their political and administrative system along the ideas of NPM. It is the reform discourse that has changed. They stopped referring to them as NPM. Some of the core elements of NPM related to new forms of political steering, however, proved to be less popular. The reforms can therefore be termed as "NPM light". When it comes to explaining the spread of the different reform activities within the country, we find evidence for the historical and sociological neo-institutionalism. There are considerable differences between language areas and between smaller and larger municipalities. Party preferences of local executives and of the citizens do not matter. The results shed new light on the debate about the assumed failure of NPM reforms.
\end{abstract}

KEYWORDS: • administrative reforms $\bullet$ municipality $\bullet$ new public management $\bullet$ Switzerland

CoRresPondence AdDress: Andreas Ladner, Ph.D., Professor, University of Lausanne, Institut de hautes études en administration publique, Swiss graduate school of public administration, Quartier UNIL Mouline, CH-1015 - Lausanne, Switzerland, email: andreas.ladnerunil.ch. 
Reforms of local governments have a long history. The allocation of functions and tasks across and between jurisdictions and the amalgamation of municipalities entered the reform agenda in the 1950s (Vetter/Kersting 2003: 16). Almost ever since, the reform debate focused on efficiency and effectiveness in the provision of goods and services on the one side, and local democracy and citizen participation, on the other side. In the 1980s, as a reaction to the expansion of the welfare state and the growth of public tasks and administrative functions, a new doctrine inspired by Anglo-Saxon countries became increasingly popular. These reforms under the name New Public Management (NPM) attempted to reduce the scope of local public administrations and to make them more competitive. The side of the citizens was supposed to be strengthened through more transparency, customer orientation and better steering possibilities for elected representatives.

The ideas of New Public Management entered the Swiss reform agenda relatively late. This is not astonishing considering Switzerland's long-lasting reluctance to address institutional reforms (Ladner 2011). It was only in the mid-1990s when various reform projects started at the different levels of the state (Haldemann/Schedler 1995:127), many of them in form of pilot projects and first trials. At the same time, the first volumes promoting the concepts of NPM were published (Schedler 1995, Hablützel et al. 1995). In the years to follow, however, the reform activities gained momentum, especially at the lower levels, in the cantons and the municipalities (Steiner 2000).

A first comprehensive assessment of NPM activities in Switzerland came to the conclusion that NPM has become a reality in Swiss public administration (see Lienhard et al. 2005: 14). The reform movement has led to a change of the administrative and political culture. Frontrunners were still the cantons. On the local level, the reforms were particularly popular in cities and large municipalities. Evaluations of NPM projects on national (Balthasar et al. 2001, Ritz 2003) cantonal (Rieder/Lehmann 2002) and local level (Steiner et al. 2006, Ladner et al. 2007) came to a generally positive assessment of the reform endeavours.

Some decade later, the picture turned into a less optimistic one. In some cantons (such as Zurich) NPM seemed to function quite well, whereas in others (like Berne) the reform was heavily criticized or even abandoned (St. Gallen, Basel-Stadt). ${ }^{1}$ On federal level, it took quite some time to increase the number of administrative units which are led by performance contracts and global budgets ("FLAG-Ämter"), and only very recently a new leadership model based on global budgets and performance contracts was decided upon. ${ }^{2}$ On local level, NPM seemed to have disappeared. Only very few municipalities still claim to do New Public Management. Hence, the question arises, whether the NPM reforms have been abandoned and proven to be a step into the wrong direction? 
Our regular monitoring of the Swiss municipalities measures the spread and proliferation of administrative reforms. Since the 1990, every five years we survey all municipalities in the country and ask them - among many other things - about ongoing reform projects. The results show that a lot of the claims of NPM have been adopted but municipalities do not refer to them as New Public Management anymore.

Switzerland is a particularly interesting case when it comes to the implementation of reforms and the way the municipalities organize their administration. First, Swiss municipalities are autonomous in their internal organization and free to adopt reforms they judge appropriate. Second, they depend on their own financial resources and citizens enjoy far reaching means of direct democracy to influence political decisions. Municipalities thus have to respect both cost-benefit considerations and the preferences of their citizens. And third, they seem to manage quite well. Satisfaction with the facilities and services provided and the functioning of local democracy is extremely high in a comparative perspective (see Denters et al. 2016, forthcoming), despite fact that the majority of the municipalities is small.

The paper starts with some theoretical considerations about New Public Management and administrative reforms. What are the different elements summarized under this concept and what can be expected in regard to the progress and the spread of these reforms in Swiss municipalities? The following sections present the data and the results. The paper ends with a discussion of the findings and an outlook.

\section{Theoretical considerations}

Prior to explaining the spread and progress of NPM reforms and answering the question whether NPM has come to an end, a clarification of the different administrative changes commonly subsumed under this concept is essential.

\section{Administrative reforms and New Public Management (NPM)}

Despite the omnipresence of the term NPM in the scholarly literature since the 1980 s, there is little agreement about the very essence of NPM, apart perhaps from that it is seen as a reaction to welfare state expansion and classical Weberian bureaucracy (Kuhlmann/Wollmann 2013: 46) and that it finds its origins in the Anglo-Saxon countries (Great Britain, Australia, New Zealand).

Part of the confusion is due to its broad scope containing regulatory elements (Kuhlmann/Wollmann 2013: 46/47) like limiting the size of the state sector, introducing market mechanism, enhancing competition and defining citizens as clients as well as micro-economic elements regarding the internal organization of the administration, processes and steering instruments, and profiles of the civil servants and leadership (for more details see Kuhlmann 2009:45). 
Another reason is its rather diffuse theoretical background. According to Aucoin (1990) there are at least two sets of ideas at the outset of NPM: The first is a privatesector-orientated managerialist ideology which was for example manifest in the Thatcher reforms whereas the second perspective is more inspired by public choice and the principle agent theory (Lynn 2005:43). This helps to understand that the political debate about NPM is not simply structured along the left-right dimension. Making the state work better by setting goals to be achieved appeals to the left whereas downsizing the state sector and more competition rather attracts the right.

NPM reforms basically touch upon three domains: (i) the organizational structure of the public sector, (ii) processes and steering instruments, and (iii) the civil service (Kuhlmann/Wollmann 2013: 209: ff.). As for the organizational structure the key concepts have been decentralization, flatter hierarchies and more autonomy of organizational units within the ministries or in the form of agencies outside the core administration. With the introduction of performance contracts, global budgeting, products and product budgets internal processes are supposed to change fundamentally, allowing for a separation of policy formulation and implementation and for output or even outcome oriented steering based on indicators, controlling and performance management. Most prominent among the civil service oriented reforms were changes in the status of civil servants, decentralization of personnelrelated responsibilities and performance-related salary systems.

These different elements of NPM have not been equally popular in all countries. The promoters of NPM in Switzerland emphasized - very much like in Germany the advantages of outcome oriented policy making (Schedler 1995). Politics should be about what has to be achieved, how it is achieved is left to the administration. Key elements were the idea of reorganizing state activities in terms of products, global budgeting giving the administrative units more leeway and performance contracts containing outcome related goals to be achieved. Nevertheless, for some adherents of the reforms, other NPM ideas were equally (or even more) important, such as bringing management elements of the private sector into the public sector, making the state leaner through outsourcing or the creation of agencies and enhancing performance orientation and competition. A thorough assessment of NPM in Swiss municipalities will have to distinguish between these different types of NPM reforms.

\section{Reform rhetoric}

Administrative reforms have been taking place before NPM became the panacea for the modernization of the public sector. New Public Management, however, managed to appear as an encompassing solution for a fundamental change of the classic encrusted bureaucratic model into a customer-friendly service enterprise (Hood 1991, Reichard 1994, Schedler and Proeller 2003). Reforms also have to be promoted and advertised. Reform rhetoric (talk) plays an important role (Brunsson 
1989). The spread of reforms increases considerably if they are perceived as a promising step in the right direction, already successfully tested in some other countries or municipalities. Often, one of the motifs to start NPM has been the idea to appear as a modern municipality. "New" sounds good. And, of course, reforms become more attractive when they promise more than just incremental improvements, but a new paradigm. But: New cannot be new for ever.

To answer the questions whether New Public Management (NPM) ${ }^{3}$ has come to an end and whether bureaucracy strikes back, as it is suggested by some authors (Drechsler 2005, Dunleavy et al. 2005), or whether we move towards a new model combining the advantages of the Weberian bureaucracy with the assets of NPM as it is suggested by others (Bouckaert 2006: $34 \mathrm{f}$., Pollit/Bouckaert 2004: $99 \mathrm{ff}$.), or even towards a new post-NPM administrative paradigm such as New Governance or Whole-of Government (Jann 2002, Dent 2005, Christensen/Langreid 2007) ${ }^{4}$, it is important to distinguish between reform rhetoric and changes taking place.

\section{Explaining the spread of administrative reforms}

From a theoretical perspective neo-institutionalist theories have found growing acceptance in the analysis and explanation of administrative reforms and transformations (March/Olsen 1984, Kuhlmann/Wollmann 2014:44). Institutions not only contain a structural suggestion to actor behaviour (Dowding 1994: 44) but also to the possibilities of change. Without being deterministic, they limit the options but leave enough room for (rational) decisions, taking into account historical and contextual restrictions and opportunities (Thelen/Steinmo 1992, DiMaggio/Powell 1991).

The different types of neo-institutionalism (Hall/Taylor 1996) must not be seen as competing or mutually exclusive but rather as different models operating at different stages and on different levels. The historical institutionalism (Steinmo et al. 1992, Peters 1999 and Pierson 2004) brings in a long term perspective limiting policy alternatives through path dependency. In a similar vein, the sociological institutionalism (DiMaggio/Powell 1991) also sets limits but on structural and cultural dimensions. By emphasizing on cognitive-cultural aspects this approach makes us not only aware of possible conflicts between formal rules and reality but also - and in line with the historical neo-institutionalism - of the different social and political realities reforms take place in.

NPM reforms in a specific country, thus, cannot be understood without taking the prevailing administrative culture and tradition into account (see Kuhlmann/Wollmann 2014: 9 ff.). Switzerland offers a particularly interesting hybrid (see Giauque 2013) - case in this respect. It is often put into the Continental European federal group together with Germany and Austria (Kuhlmann/Wollmann 2014: 17) but there are some quite important differences. It is less legalistic in following the Roman rule-of-law tradition and has a more open and flexible civil 
service which deviates from the Prussian model. This brings the system closer to the Scandinavian model or together with the less dominant role of the state closer to the Anglo-Saxon model. The different language areas provide additional complexity. In the French speaking part elements of the Continental European Napoleonic model are more influential leading to a stronger and more centralized state sector when it comes to the organization of the cantons and their municipalities.

The hybrid character, however, makes it difficult to predict the form and extent of NPM reforms in general, since they are supposed to differ according to the prevailing administrative tradition. Following the Continental European federal model, one would expect more formal (corporatization) and functional (outsourcing) privatization than privatisation of municipal assets, some persistence when it comes to performance management and resistance against introducing performance related payments and more flexibility in public employment (Kuhlmann/Wollmann 2014: 268 ff.). Or more generally, one would expect a rather moderate internal modernization of the local public administration.

Focusing more directly on change and concrete reform projects, the historical neoinstitutionalism suggests stability and limited possibilities for fundamental changes (Ladner 2011: 154). It contains, however, concepts such as "critical junctures", "windows of opportunity" or "external pressure" which offer possibilities to break the chains of path dependency. The sociological neo-institutionalism favors incremental adaption to a changing environment. Most prominent here are the different forms of isomorphism linked up with policy learning. DiMaggio and Powell (1991) distinguish between imitation (mimetic isomorphism), adaption as a result of force (coercive isomorphism) or normative pressure (normative isomorphism).

Ration choice oriented or actor centered neo-institutionalisms (Mayntz/Scharpf 1995, Ostrom et al. 1994) also conceptualize the limitations of institutions but emphasize on the actors involved and their strategic decisions. They leave more room for freedom of choice, initiation and prevention of reform programs and implementation measures (Kuhlmann/Wollmann 2014: 46) and for the constellation of actors involved. Reforms are likely to be seen as the product of rational costbenefit calculation based on a fixed repertoire of preferences. Institutional reforms thus not only happen, they are made. But what makes them particular is that they address the framework in which they take place. They aim at changing the "rules of the game". Reforms can thus be seen as a polity-policy (Wollmann 2000: 199) emphasizing on goals, interventions, activities, results and effects (Jann 2001: 329).

Drawing upon the different theoretical concepts outlined above, we can formulate our expectations regarding the spread of administrative reforms in Swiss municipalities (see Table 1): 
Following the arguments of the historical and sociological neo-institutionalism emphasizing on history and context we expect Swiss municipalities to be relatively open to administrative reforms subsumed under the concept of New Public Management since Switzerland has a relatively open state sector and cooperation with the private sector is traditionally quite intensive (Ladner 2013). The reforms are also likely to spread unevenly across the country because there are important cultural differences between the language areas when it comes to the role of the state and the autonomy of municipalities. We expect the resistance against reforms challenging the state as the unique provider of public services and the introduction of market mechanism to be stronger in the French speaking part than in the German speaking part of the country.

But it is not only the historical and cultural context that matters, structural elements also can have an influence. If reforms touch upon the internal organization of the administration and its processes and try to make them more efficient and effective, a minimal size of the local administration seems to be a necessary precondition. Since many Swiss municipalities are very small having not more than a few hundred inhabitants we might not expect them to have conducted any significant NPM reforms. Municipalities also need the necessary capacity in terms of resources, personnel and knowledge in order to conduct reforms (Rieder/Widmer 2007: 47).

Another characteristic of Swiss municipalities is their fiscal and financial autonomy. More or less as a direct result of this, there are important differences as far as their financial resources are concerned. One of the important questions is whether financial problems lead municipalities to undertake reforms. There are reasons to believe that this is the case, but if we consider that fact that reforms are also costly, the expectations become less clear. Whereas difficulties municipalities are confronted with while providing services and fulfilling their tasks most probably lead to changes of the internal structure and the functioning of the local administration.

With respect to federalist countries we know that veto points (Tsebelis 2002) may play an important role when it comes to the implementation of political programs. Thus, comprehensive NPM reforms are more likely to be conducted in unitary countries (Pollitt/Bouckaert 2004: 41 ff.). This might at least be the case where topdown reforms are feasible. In a similar vein it can be argued that a high municipal autonomy makes it more difficult to implement comprehensive administrative reforms touching upon all municipalities. Against this, however, stands the argument that local autonomy gives the municipalities the possibility to conduct reforms whenever they judge it necessary and that is has a positive impact on appropriate changes. Here again, we leave it open whether local autonomy has a positive or negative effect on reforms. 
Table 1: Independent variables hypotheses, theoretical argument and operationalization

\begin{tabular}{|c|c|c|c|}
\hline $\begin{array}{l}\text { Independent } \\
\text { Variable }\end{array}$ & $\begin{array}{l}\text { Hypothesis } \\
\text { (expected } \\
\text { correlation) }\end{array}$ & $\begin{array}{l}\text { Theoretical } \\
\text { Background }\end{array}$ & Operationalization/Measurement \\
\hline Size & $\begin{array}{l}\text { More reforms in } \\
\text { larger } \\
\text { municipalities }(+)\end{array}$ & $\begin{array}{l}\text { Sociological neo- } \\
\text { institutionalism, } \\
\text { context matters }\end{array}$ & $\begin{array}{l}\text { Number of inhabitants in a } \\
\text { municipalities 2009, (natural } \\
\text { logarithm) }\end{array}$ \\
\hline Language & $\begin{array}{l}\text { Fewer reforms in } \\
\text { the French and } \\
\text { Italian speaking } \\
\text { parts (-), no } \\
\text { managerial } \\
\text { reforms }\end{array}$ & $\begin{array}{l}\text { Sociological neo- } \\
\text { institutionalism, } \\
\text { context matters }\end{array}$ & $\begin{array}{l}\text { Municipality belongs to French } \\
\text { speaking part of the country }(=1) \text {, } \\
\text { Municipality belongs to the } \\
\text { Italian speaking part of the } \\
\text { country }(=1)\end{array}$ \\
\hline Finances & $\begin{array}{l}\text { Financial } \\
\text { problems } \\
\text { foster/hinder } \\
\text { reforms }(+/-)\end{array}$ & $\begin{array}{l}\text { Historical and } \\
\text { rational choice neo- } \\
\text { institutionalism, } \\
\text { external pressure, } \\
\text { window of } \\
\text { opportunity, } \\
\text { problem solving }\end{array}$ & $\begin{array}{l}\text { Budget deficit (average value } \\
\text { over the past three years) } 2009 \\
\text { Receives money from the } \\
\text { financial equalization scheme }\end{array}$ \\
\hline $\begin{array}{l}\text { Performance } \\
\text { problems }\end{array}$ & $\begin{array}{l}\text { Performance } \\
\text { problems lead to } \\
\text { NPM reforms (+) }\end{array}$ & $\begin{array}{l}\text { Rational choice neo- } \\
\text { institutionalism, } \\
\text { problems lead better } \\
\text { solutions }\end{array}$ & $\begin{array}{l}\text { Average value for performance } \\
\text { problems across } 32 \text { tasks, } 2009\end{array}$ \\
\hline Local autonomy & $\begin{array}{l}\text { Autonomy gives } \\
\text { the municipalities } \\
\text { the possibility to } \\
\text { start reforms/to } \\
\text { abstain from } \\
\text { reforms }(+/-)\end{array}$ & $\begin{array}{l}\text { Actor centered neo- } \\
\text { institutionalism }\end{array}$ & $\begin{array}{l}\text { Perceived perception of local } \\
\text { autonomy on a scale from } 1 \text { (no } \\
\text { autonomy )to } 10 \text { (a lot of } \\
\text { autonomy), } 2009\end{array}$ \\
\hline Party preferences & $\begin{array}{l}\text { Strong Liberal } \\
\text { Party in the local } \\
\text { executive leads to } \\
\text { more reforms (+) } \\
\text { High percentage of } \\
\text { left-wing voters } \\
\text { leads to less NPM } \\
\text { reforms (-) }\end{array}$ & $\begin{array}{l}\text { Actor centered neo- } \\
\text { institutionalism, } \\
\text { "parties matter" }\end{array}$ & $\begin{array}{l}\text { Percentage of member of the } \\
\text { Liberal Party (FDP) in the local } \\
\text { executive (2009) } \\
\text { Percentage of left-wing voters in } \\
\text { national elections (2007) }\end{array}$ \\
\hline $\begin{array}{l}\text { Canton is NPM } \\
\text { pioneer }\end{array}$ & $\begin{array}{l}\text { If canton is NPM } \\
\text { pioneer, } \\
\text { municipalities are } \\
\text { more likely to start } \\
\text { NPM reforms (+) }\end{array}$ & $\begin{array}{l}\text { Sociological neo- } \\
\text { institutionalism, } \\
\text { mimetic, normative } \\
\text { and to a lesser extent } \\
\text { coercive } \\
\text { isomorphism } \\
\end{array}$ & $\begin{array}{l}\text { Canton is a NPM pioneer } \\
\text { (Rieder/Widmer }\end{array}$ \\
\hline
\end{tabular}

Relying on the reasoning of the actor centered neo-institutionalism we are also interested in the dominant party in the decisive body of the municipality. The party most likely to support NPM reforms is the Liberal Party (FDP) which has the strongest sympathies for models deriving from the private sector and for market mechanism. From the citizens' side we are interested in the electoral strength of the left as a possible restrictive force for when it comes to organizational changes and outsourcing. Unlike other countries, the most important changes of the internal 
organization of the local public sector in Swiss municipalities need the consent of the citizens at the polls which makes them an important actor, too.

A final variable that shall be tested is what can be termed the vertical diffusion of NPM. Although local autonomy makes it difficult for cantons to impose administrative reforms on their municipalities they might go ahead giving a good example themselves. If the canton is among the frontrunners of NPM reforms for its own administration, we also expect to find more municipalities with NPM reforms in this canton. We can in most cases exclude coercive isomorphism but we might find signs of mimetic or normative isomorphism. Diffusion models can, of course, also work horizontally and explain why reforms are more frequent in specific areas which could additionally account for within-country differences according to the dominant language.

And finally, not all elements out of the huge basket of NPM reforms follow the same logic and have the same consequences for the role and the functioning of the state sector within society, and they are most probably not equally possible and effective, depending for example on the type of a municipality. If municipalities are small and only have very limited administrative capacities, outsourcing and a stronger cooperation with the private sector might be a necessity. Or, left-wing parties might welcome a thorough evaluation of the impact of state activities and improved steering functions and object at the same time a downsizing of the state sector, more competition among municipalities and performance related salaries.

\section{$3 \quad$ Methodological considerations and data}

In countries where municipalities enjoy a considerable degree of autonomy when it comes to the organization of their political system, their administration and their financial resources, the spread and the extent of reform activities cannot be assessed centrally but has to be established at the level of the municipalities themselves. Since 1988 we conduct in regular intervals surveys addressing the totality of the Swiss municipalities. Our respondents are the municipal secretaries. They hold a key management position within the municipal administration. In many municipalities he or she is the highest level civil servant working at the interface between administration and politics. The municipal secretaries proved to be very reliable informants. They are often more objective about the achievements of their municipalities than the elected politicians in charge. In 1998, 84.5 percent of the, at that time, 2914 municipalities participated in our survey, in 2005 the participation rate was 79.2 per cent out of 2771, and in 2009 it was 57.7 per cent out of 2596 municipalities.

The reach of your data allows us to draw an accurate picture of the reform activities in the whole country. There are, however, also some problems related to this method of data collection. Like in any survey, we have to believe our respondents. They 
might, for example, be likely to pretend that their municipality is very active in terms of reforms, especially if they also play an important part in the reform process. And perhaps even more importantly, it is not easy to guarantee that the questions are understood equally, especially when they are asked in three different languages. The answer to the question whether they reformed their municipality according to the principle of NPM depends on their understanding of NPM which is, as we have seen, far from clear. This is of lesser importance when we remain on the level of the reform discourse but it is obviously crucial when we want to learn more about their reform activities. Here, we have to be very specific and we have to ask them what exactly - if anything - they have changed in recent years.

To obtain a more in-depth view, it would, if course, be preferable to look at the different reform activities in every municipality and capture all the changes taking place. Considering the high number of municipalities, however, this is not feasible. A more quantitative analyses of recent administrative reforms in a carefully selected sample of municipalities will be in the center of a future research project.

\section{$4 \quad$ NPM and administrative reforms}

Our surveys allow distinguishing between reform rhetoric and concrete changes Swiss municipalities were implementing since the 1990 s. ${ }^{5}$ First, we will look at the question in which we as the municipalities whether they have undertaken NPM reforms.

In the late 1990s, the answers of our respondents were quite promising for the promoters of NPM (Ladner 2005): More than one third of them claimed that they were talking about NPM reforms in their municipality, and about one quarter stated that they had made some attempts to introduce NPM or planned NPM reforms (see Table 2). Seven years later, however, the picture had completely changed. About 90 per cent of the municipalities denied doing NPM. Only five per cent of the municipalities had implemented NPM by then, three per cent were doing tests with such reform ideas, and two per cent stopped their NPM reforms. The 2009 survey confirmed the result of 2005. According to these latest results, there seems to be a clear backward trend in terms of NPM reform activities with between 15 and 25 per cent of the municipalities renouncing to NPM and almost no new municipalities joining the reform movement. Interesting to note, however: About 75 per cent (74.6\%, N=319) of those municipalities which claimed to plan NPM reforms in 1998 and nearly 80 per cent $(78.1 \%, N=347)$ of those which had already undertaken first steps with such reforms denied having had NPM reform projects in their municipality in earlier times. 
Table 2: $\quad$ Municipalities doing NPM in 1998, 2005 and 2009 (percentages)

\begin{tabular}{|l|l|l|l|l|}
\hline 1998 & Yes & & & $\mathrm{N}=$ \\
\hline $\begin{array}{l}\text { NPM has been seriously } \\
\text { discussed }\end{array}$ & 34.7 & & & 2437 \\
\hline NPM reforms are planned & 23.8 & & & 2408 \\
\hline $\begin{array}{l}\text { First steps with NPM have been } \\
\text { undertaken }\end{array}$ & 25.3 & & & 2333 \\
\hline & & & & \\
\hline NPM reforms ... & $\begin{array}{l}\text { permanently } \\
\text { introduced }\end{array}$ & $\begin{array}{l}\text { experimentally } \\
\text { introduced }\end{array}$ & stopped & \\
\hline 2005 & 4.7 & 3.0 & 1.6 & 2162 \\
\hline 2009 & 5.0 & 2.8 & 2.1 & 1400 \\
\hline
\end{tabular}

NPM reforms seem to have completely disappeared from the reform agenda, if we believe the results presented above. Only a very small number of municipalities still follow the principles of New Public Management. But the question is: Have there been no changes at all?

In our survey we additionally enumerated a wide range of possible changes and reforms and asked the municipal secretaries whether they implemented some of them in their municipality. The possible projects ranged from very straight forward core element of NPM such as the definition of products, global budgeting and performance contracts to more general reforms such as outsourcing, delegating more competences to the administration or abolishing the special status of civil servants. We also included some reforms which can be but do not necessarily have to be called NPM reforms such as conducting customer surveys, relying on external experts or the development of mission statements for the future development of the municipality.

Figure 1 shows the popularity of the different reform activities. They are presented along the three different types of reforms - organization of the public sector, processes and steering instruments and civil service - described in the theoretical part of this paper. The figure shows the percentages of municipalities having undertaken these reforms in 1998 and 2009.

The first group of reforms concerns organisational matters such as the reallocation of competences (towards the administration), a clearer distinction between strategic and operational tasks, an increasing use of external experts, outsourcing of public tasks and public private partnership. Apart from PPP such reforms have become increasingly popular among Swiss municipalities with between 30 and a bit more than 40 percent of municipalities having implemented them compared to about 10 percent ten years ago. 
When it comes to procedural reforms the picture becomes more ambivalent. On the one side, we find attempts to introduce a mid- and long-term perspective through mission statements, a stronger integration of the citizens' demands, more competition through new forms of comparing costs and controlling systems which have been undertaken by about one third of the municipalities. On the other side, there are elements such as the definition of products and global budgeting which should allow for more output-oriented policy making which have not attracted more than ten percent of the municipalities. This latter result is a disappointment for the promotors of NPM in Switzerland since these elements have been considered crucial for the new steering model they wanted to introduce.

And finally, there have been some considerable changes in the field of human resources. More than half of the municipalities have abolished the special status of civil servants and about one third have introduced performances related pay. The "abolishment" of civil servants has become the most popular reform activity.

The closer look at the progress of reform activities leads to two noteworthy conclusions. Despite the decreasing popularity of NPM as such, there has been a considerably increase of reforms which have been termed NPM reforms previously. Obviously, quite a few municipalities have introduced NPM reforms but they are no longer referring to them as NPM reforms. In other words, it is the reform discourse which has changed; the implementation of NPM elements has even increased and NPM has been quite successful in changing public administration on local level.

The first group of reforms concerns organisational matters such as the reallocation of competences (towards the administration), a clearer distinction between strategic and operational tasks, an increasing use of external experts, outsourcing of public tasks and public private partnership. Apart from PPP such reforms have become increasingly popular among Swiss municipalities with between 30 and a bit more than 40 percent of municipalities having implemented them compared to about 10 percent ten years ago.

When it comes to procedural reforms the picture becomes more ambivalent. On the one side, we find attempts to introduce a mid- and long-term perspective through mission statements, a stronger integration of the citizens' demands, more competition through new forms of comparing costs and controlling systems which have been undertaken by about one third of the municipalities. On the other side, there are elements such as the definition of products and global budgeting which should allow for more output-oriented policy making which have not attracted more than ten percent of the municipalities. This latter result is a disappointment for the promotors of NPM in Switzerland since these elements have been considered crucial for the new steering model they wanted to introduce. 
And finally, there have been some considerable changes in the field of human resources. More than half of the municipalities have abolished the special status of civil servants and about one third have introduced performances related pay. The "abolishment" of civil servants has become the most popular reform activity.

The closer look at the progress of reform activities leads to two noteworthy conclusions. Despite the decreasing popularity of NPM as such, there has been a considerably increase of reforms which have been termed NPM reforms previously. Obviously, quite a few municipalities have introduced NPM reforms but they are no longer referring to them as NPM reforms. In other words, it is the reform discourse which has changed; the implementation of NPM elements has even increased and NPM has been quite successful in changing public administration on local level.

Figure 1: Diferent reform activities 1998 and 2009 (percentages)

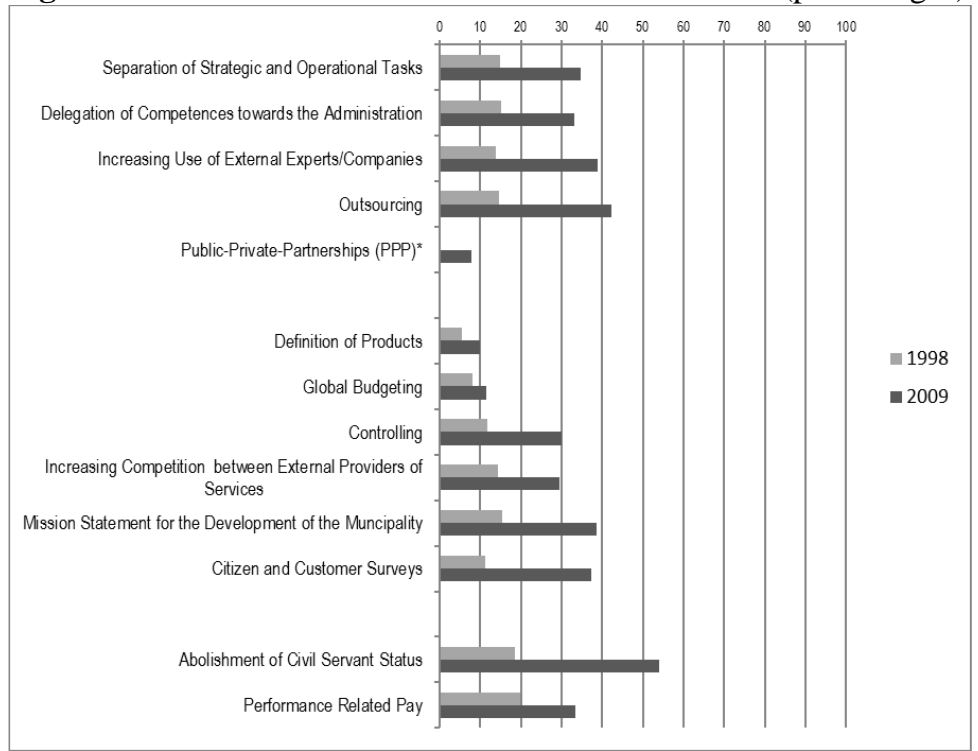

Source: Local Secretary Surveys 1998 and 2009

Percentages, $\mathrm{N}=1132$, panel data;

* Question has not been asked in 1998

And secondly, the core elements of NPM such as outcome oriented forms of steering the administration through the definition of products which are directly linked their costs have only been taken up by a small group of municipalities. This leads us to the conclusion that Swiss municipalities have opted quite pragmatically for a form of "NPM light", integrating some aspects of the reform proposal, only. If these reforms hold their promises local politics should become at least more 
visionary and citizens or customer oriented, and the local administration more competitive and business or market oriented.

In a next step we turn our attention towards to the municipalities and their reform preferences. Not all municipalities have been attracted by the whole range of reforms the same way. By the means of an exploratory factor analysis we can see which reforms activities are likely to ocurr together. Table 3 reveals four major reform patterns.

A first pattern combines HR elements such as the abolishment of the civil service status and performance related pay. Other variables of lesser importance are mission statements for the development of the municipality and planning for the term of a legislature, and more citizen oriented measures such as surveys and the provision of services through the internet (eGovernment).

The second pattern concerns the allocation of competences between elected politicians and the administration. It combines a separation between strategic and operational activities and the delegation of competences towards the administration.

The third pattern contains, as we expected, the two key elements of NPM in a stricter sense addressing the so called new form of steering the activities of the administration through the definition of products and global budgets.

The fourth pattern, finally, combines outsourcing and an increased collaboration with external providers of services.

These four patterns follow at least partially the different categories of NPM reforms. The first factors takes up the reorganization of the civil service and combines it to some extent with a more forward looking and citizens oriented local public sector. Organizational reforms are contained in two different factors, a first one reallocating competences within the administration and a second one which increases cooperation with the private sector. The two key elements of procedural reforms, products and global budgeting form the fourth factor. These four factors also remain unchanged when we conduct the factor analysis for the German or the French speaking municipalities separately and when we look at the municipalities with more than 5000 inhabitants only. 
Table 3: $\quad$ Patterns of NPM - reforms (Factor Analysis)

\begin{tabular}{|l|l|l|l|l|}
\hline & $\begin{array}{l}\text { HR } \\
\text { reforms } \\
\text { mission } \\
\text { statement } \\
\text { (factor 1) }\end{array}$ & $\begin{array}{l}\text { Reallocatio } \\
\mathrm{n} \text { of } \\
\text { competenc } \\
\text { es (strategy } \\
\text { and } \\
\text { operation) } \\
\text { (factor 2) }\end{array}$ & $\begin{array}{l}\text { NPM hard } \\
\text { core } \\
\text { elements } \\
\text { (products, } \\
\text { global } \\
\text { budget) } \\
\text { (factor 3) }\end{array}$ & $\begin{array}{l}\text { Outsourcin } \\
\text { g, external } \\
\text { experts } \\
\text { (factor 4) }\end{array}$ \\
\hline $\begin{array}{l}\text { Separation of Strategic and Operational } \\
\text { Tasks }\end{array}$ & .161 & .845 & .071 & .104 \\
\hline $\begin{array}{l}\text { Delegation of Competences towards the } \\
\text { Administration }\end{array}$ & .124 & .848 & .000 & .065 \\
\hline Global Budgeting & -.009 & .077 & .775 & -.056 \\
\hline Finance Planning & .324 & .223 & .180 & .225 \\
\hline Legislature Planning & .503 & .256 & .256 & .065 \\
\hline Definition of Products & .107 & .180 & .722 & .006 \\
\hline Performance and Service Contracts & .319 & .153 & .384 & .326 \\
\hline Controlling & .224 & .392 & .222 & .226 \\
\hline Abolishment of Civil Servant Status & .722 & .053 & -.143 & .105 \\
\hline Performance Related Pay (PRP) & .701 & .122 & .009 & .001 \\
\hline $\begin{array}{l}\text { Organization and Personnel } \\
\text { Development }\end{array}$ & .418 & .404 & .213 & .215 \\
\hline $\begin{array}{l}\text { Increasing Use } \\
\text { Experts/Companies }\end{array}$ & .057 & .095 & .027 & .773 \\
\hline Outsourcing External & .110 & .116 & .044 & .760 \\
\hline Public-Private-Partnership (PPP)* & -.001 & -.095 & .515 & .255 \\
\hline $\begin{array}{l}\text { Promoting Competition } \text { between } \\
\text { External Services }\end{array}$ & .217 & .130 & .322 & .359 \\
\hline $\begin{array}{l}\text { Mission Statement for the Development } \\
\text { of the Municipality }\end{array}$ & .608 & .114 & .190 & .103 \\
\hline Citizen and Customer Surveys & .431 & -.018 & .247 & .125 \\
\hline eGovernment & .527 & .296 & -.196 & .049 \\
\hline $\begin{array}{l}\text { Extraction: Principal component. Rotation } \\
\text { Variance: 46,7\% }\end{array}$ & method: Varimax with Kaiser normalization. Explained \\
\hline
\end{tabular}

Let us look in the final part of this section at the importance of the different reform patterns and to what extent they occur in combination with each other. Hereby we concentrate on the most important elements of the four NPM-reform patterns found in the previous factor analysis. ${ }^{6}$ Table 4 shows that less than five percent of the municipalities conducted changes containing the core elements from of all four NPM-reform patterns. These hardcore reformers are in general larger municipalities: The average population size of the 65 municipalities amounts to almost 50'000 inhabitants. Municipalities without any reforms at all, are very small with an average population size of 2'500 inhabitants. They account for a bit more than 20 percent of the municipalities. Frequent constellations are HR-reforms, reallocation of competences and outsourcing without new forms of steering (13.9 per cent of the municipalities), HR-reforms and outsourcing (12.4 per cent), and HR reforms only (10.4 per cent). The new product oriented steering of public services combined with global budgets proves again to be the rare centerpiece of a more 
encompassing reform of the local public sector. Most popular on the contrary are HR reforms and outsourcing of any kind. Taken all together, it comes out clearly that NPM in Swiss municipalities has different faces putting the emphasis on different elements of the whole reform package.

Table 4: $\quad$ NPM Reform patterns and language area (average factor scores)

\begin{tabular}{|c|c|c|c|c|c|}
\hline $\begin{array}{l}\text { HR reforms } \\
\text { (abolishment } \\
\text { civil servants } \\
\text { and/or } \\
\text { performance } \\
\text { related pay) }\end{array}$ & $\begin{array}{l}\text { Reallocation of } \\
\text { competences } \\
\text { (delegation and/or } \\
\text { strategy and } \\
\text { operation) }\end{array}$ & 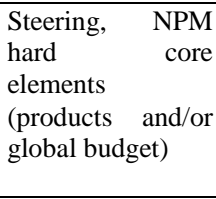 & $\begin{array}{l}\text { Outsourcing } \\
\text { and/or external } \\
\text { experts }\end{array}$ & Percentages & $\mathrm{N}=$ \\
\hline$X$ & $X$ & & $\mathrm{X}$ & 13,9 & 208 \\
\hline$X$ & & & $\mathrm{X}$ & 12,4 & 186 \\
\hline \multirow[t]{2}{*}{$\bar{X}$} & & & & 10,4 & 156 \\
\hline & & & $X$ & 9,8 & 146 \\
\hline \multirow[t]{2}{*}{$X$} & $X$ & & & 6,9 & 103 \\
\hline & $X$ & & $X$ & 4,7 & 71 \\
\hline \multirow[t]{5}{*}{$X$} & $X$ & $X$ & $X$ & 4,3 & 65 \\
\hline & $\bar{X}$ & & & 3,7 & 55 \\
\hline & $\bar{X}$ & $\bar{X}$ & $\mathrm{X}$ & 2,5 & 38 \\
\hline & & $X$ & $X$ & 2,1 & 31 \\
\hline & & $\mathrm{X}$ & & 2,1 & 32 \\
\hline$X$ & $X$ & $X$ & & 1,8 & 27 \\
\hline$X$ & & $X$ & $X$ & 1,4 & 21 \\
\hline \multirow[t]{5}{*}{$\mathrm{X}$} & & $X$ & & 1,1 & 16 \\
\hline & $\mathrm{X}$ & $\mathrm{X}$ & & 1,0 & 15 \\
\hline & & & & 21,8 & 327 \\
\hline & & & & & \\
\hline & & & & 100 & 1497 \\
\hline
\end{tabular}

\section{$5 \quad$ Explaining the spread of administrative reforms}

In this section, we will finally test our hypothetical expectations about the spread of NPM and administrative reforms in Swiss municipalities outlined in section 2. There, we expected the size of the municipality, the location in the language areas of the country, the financial situation and difficulties to cope with policy challenges, the autonomy of the municipalities, the party composition of the executive and the political preferences of the citizens, and the fact that the canton is a frontrunner in terms of NPM reforms to have an impact on the municipalities' propensity to undertake reforms.

As for the reforms - the dependent variable - we use six different measures: The answer to the question whether the municipalities have started a reform project under the heading of NPM in recent years, an index adding up the different reform 
activities presented in table 3 , and the four reform patterns (factor scores) from the factor analysis of the previous section, as indicators for reforms in the domain of human resources, internal organizational reforms (reallocation of competences), a stronger collaboration with the private sector (outsourcing), and procedural reforms (steering with products and global budgeting). The results are presented in Table 5 .

Population size obviously is the most important variable explaining NPM and administrative reforms in Swiss municipalities. The coefficients are positive in all six models tested. This is not astonishing when we consider the fact that a huge number of Swiss municipalities are very small and barely have an administration which can be reformed extensively. About 40 percent of the municipalities have less than 500 inhabitants and their administration consists only of the municipal secretary.

When it comes to cultural differences, the French speaking part of the country turns out to be less inclined to undertake NPM reforms and the same holds true for administrative reforms in general. French speaking municipalities particularly reject HR-reforms and a reallocation of competences whereas they are rather inclined to define state activities in terms of products and to apply global budgeting. This latter result is in so far astonishing as it is the key elements of NPM which are supposed to improve political steering which are popular and NPM as such is not. Perhaps this can be explained by a rather negative image of NPM reforms at the beginning of the reform movement in the French speaking municipalities and their interest in making state work better. The municipalities in the Italian speaking part also reject HR reforms but they favor new steering possibilities and a shift reallocation of competences at the same time.

Financial pressure (expenditure surplus and dependency on equalization transfers) cannot clearly be made responsible for extensive reform activities. Although there seems to be a slight inclination of municipalities with an expenditure surplus or depending on equalization transfers to claim that they are undertaking NPM reforms, there are no clear indications that they really started concrete reform projects. As for the perceived performance limits which measure whether municipalities are confronted with increasing challenges and problems in different public policies, municipalities seem to react with organizational reforms (reallocation of competences and outsourcing) rather than with HR or procedural reforms.

Municipalities enjoying - according to them - a higher degree of autonomy seem to be more inclined to start NPM projects but there are no clear signs of extensive reform activities apart from reallocating competences within the administration. This still leaves us rather uncertain about the effect of autonomy on municipal reforms. Whereas for the political preferences of the local executive and the citizens 
the results are quite clear: They do not have an influence in any of our models which clearly indicates that neither NPM nor concrete administrative reforms follow party lines. NPM reforms on higher level finally do not lead to more NPM on local level. There are more administrative reforms and more municipalities are outsourcing a part of their activities in NPM pioneer cantons, but NPM as a rhetoric is not particularly more popular.

To summarize the results in a theoretical perspective we find that structural and cultural elements clearly seem to matter which supports the claims of the historical and sociological neo-institutionalism. It is basically population size and language area which explain the spread of administrative reforms in Swiss municipalities. Financial pressure and policy problems, however, do not seem to operate as important windows of opportunities for extensive reforms. As for the actor centered neo institutionalism the results are less favorable. Local autonomy is of minor importance and parties do not seem to matter. Finally, there is some evidence for the vertical diffusion model, but again, the results only provide weak support.

Table 5: $\quad$ Administrative reforms 2009

\begin{tabular}{|l|l|l|l|l|l|l|}
\hline & $\begin{array}{l}\text { Model 1: } \\
\text { NPM } \\
\text { projects }\end{array}$ & $\begin{array}{l}\text { Model 2: } \\
\text { Administra- } \\
\text { tive reforms }\end{array}$ & $\begin{array}{l}\text { Model 3: } \\
\text { Human } \\
\text { Resources }\end{array}$ & $\begin{array}{l}\text { Model 4: } \\
\text { Reallocation } \\
\text { of Compe- } \\
\text { tences }\end{array}$ & $\begin{array}{l}\text { Model 5: } \\
\text { Products } \\
\text { and Global } \\
\text { Budgeting }\end{array}$ & $\begin{array}{l}\text { Model 6utsourcing } \\
2009\end{array}$ \\
\hline $\begin{array}{l}\text { Inhabitants } \\
\text { (log.) }\end{array}$ & $0.268^{* * *}$ & $0.483^{* * *}$ & $0.334^{* * * *}$ & $0.259^{* * *}$ & $0.273^{* * *}$ & $0.069^{*}$ \\
\hline $\begin{array}{l}\text { French } \\
\text { speaking part }\end{array}$ & $-0.106^{* * *}$ & $-0.176^{* * *}$ & $-0.346^{* * *}$ & $-0.221^{* * *}$ & $0.441^{* * *}$ & -0.030 \\
\hline $\begin{array}{l}\text { Italian } \\
\text { speaking part }\end{array}$ & 0.058 & $-0.060^{*}$ & $-0.196^{* * *}$ & $0.097^{* * *}$ & $0.089^{* * *}$ & 0.009 \\
\hline $\begin{array}{l}\text { Expenditure } \\
\text { surplus }\end{array}$ & $0.064^{* *}$ & 0.026 & 0.006 & 0.029 & 0.013 & -0.005 \\
\hline $\begin{array}{l}\text { Dependent on } \\
\text { equalization } \\
\text { transfers }\end{array}$ & $-0.061^{*}$ & -0.027 & -0.020 & -0.023 & 0.004 & -0.018 \\
\hline $\begin{array}{l}\text { Performance } \\
\text { limits } \\
\text { perceived }\end{array}$ & -0.001 & 0.018 & $-0.058^{*}$ & $0.064^{*}$ & $-0.070^{* *}$ & $0.083^{* *}$ \\
\hline $\begin{array}{l}\text { Municipal } \\
\text { Autonomy }\end{array}$ & $0.102^{* * *}$ & 0.030 & -0.024 & $0.065^{*}$ & 0.016 & 0.019 \\
\hline
\end{tabular}


LEX LOCALIS - JOURNAL OF LOCAL SELF-GOVERNMENT

A. Ladner: Administrative Reforms in Swiss Municipalities over the Last

Twenty Years - The end of New Public Management?

\begin{tabular}{|l|l|l|l|l|l|l|}
\hline $\begin{array}{l}\text { Liberal Party } \\
\text { in Executive } \\
\text { (percentage) }\end{array}$ & -0.022 & 0.004 & 0.011 & 0.001 & -0.003 & 0.004 \\
\hline $\begin{array}{l}\text { Left wing } \\
\text { voters } \\
\text { percentage) }\end{array}$ & 0.013 & -0.026 & -0.041 & 0.039 & -0.029 & 0.010 \\
\hline $\begin{array}{l}\text { Canton is } \\
\text { NPM pioneer }\end{array}$ & -0.004 & $0.095^{* * *}$ & 0.040 & 0.017 & 0.035 & $0.089^{* *}$ \\
\hline & & & & & & \\
\hline N & 963 & 973 & 840 & 840 & 840 & 840 \\
\hline Rsquare adj. & 0.104 & 0.334 & 0.340 & 0.143 & 0.193 & 0.014 \\
\hline
\end{tabular}

\section{$6 \quad$ Conclusion and Discussion}

Probably the most astonishing result of this paper is the fact that Swiss municipalities engaged in a huge amount of administrative reforms without referring to them as New Public Management. The closer look at the reform activities clearly reveals a growing number of changes in the last few years which belong to the reform package of NPM, at least in a larger sense. This leads to the conclusion that New Public Management has become Public Management and is no longer considered to be something special. NPM has basically lost its attractiveness as a reform discourse.

Bureaucracy in case of the Swiss municipalities did not strike back. Local public administrations have become more considerate, citizens oriented, outcome and forward looking and they are also more open towards the private sector and its practices. Like in countries such as Germany (Kuhlmann et al. 2008: 860) or New Zealand (Lodge/Gill 2010), Swiss municipalities seem to combine the advantages of the "Weberian bureaucracy" with the positive assets of NPM. The reforms, of course, did not fundamentally change the "old" system like some of its promoters have suggested. Core elements such as new forms of political steering, the definition of products and global budgeting have proved to be less popular. In the shape of "NPM light", however, the reform movement has been very successful.

From a theoretical perspective the results contribute to a better understanding of the driving forces behind reforms. Intra-country differences concerning the spread of the reforms can best be explained within the framework of the historical and sociological neo-institutionalism. Population size and the language area are the most important variables explaining the municipalities' propensity to engage in reforms. A minimal population size is needed to make reforms effective. In the more Napoleonic and state oriented French speaking municipalities, the new steering possibilities based on products and global budgeting seem to be more attractive whereas in the German speaking part reforms are more frequent and we find 
stronger support for managerial reforms and private sector solution. Windows of opportunities in form of financial pressure or difficulties to provide specific services cannot be neglected but proved to be of lesser importance. There also is some evidence for diffusion model, but again the influence is rather weak.

We did not find much support for the actor centered neo-institutionalism. This is could be due to one of the shortcomings of this paper. Our data does not cover all the different actors possibly involved in reform project. For more insight in this respect and to overcome a the dangers inherent in survey data, our research agenda foresees more comprehensive case studies for which the cases are selected on the basis of our survey results.

\section{Acknowledgment}

An earlier version of this paper was presented at the EGPA conference 2013 in Edinburgh, Scotland.

\footnotetext{
Notes

${ }^{1}$ According to Heimgartner/Dietrich (2008) there are 11 out of 26 cantons which abstained from organizing their finances according to the principles of NPM.

${ }^{2}$ Interesting to note that in connection with this new model named "Neues Führungsmodell Bundesverwaltung (NFB) the term NPM has completely disappeard.

${ }^{3}$ For the basic ideas of NPM reforms see Osborne/Gaebler (1992) and Hood (1991).

${ }^{4}$ For a discussion of the different so-called post-NPM models see Goldfinch/Wallis (2010: 1104 ff.).

${ }^{5}$ For a first assessment of NPM reforms in Swiss municipalities see also Steiner (2000).

${ }^{6}$ HR-reforms $=$ abolishment of civil servant status and/or performance related pay; reallocation of competences $=$ separation of strategic and operational task and/or delegation of competences towards the administration; steering $=$ definition of products and/or global budgeting; outsourcing = outsourcing and/or increasing use of external experts/companies.
}

\section{References}

Aucoin, P. (1990) Administrative Reform in Public Management: Paradigms, Principles, Paradoxes and Pendulums, Governance, 3(2), pp. 115-137.

Balthasar, A. (2001) Evaluation FLAG. Gesamtbeurteilung; Bericht im Auftrag des Eidg. Personalamtes (Bern).

Bouckaert, G. (2006) Die Dynamik von Verwaltungsreformen. Zusammenhänge und Kontexte von Reform und Wandel, In: Werner, J., Bogumil, J., Bouckaert, G., Budäus, D., Holtkamp, L., Kissler, L., Kuhlmann, S.., Mezger, E., Reichard, C. \& Wollmann, H. (eds.) Status-Report Verwaltungsreform - Eine Zwischenbilanz nach 10 Jahren (Berlin: Edition Sigma), pp. 22-35.

Brunnson, N. (1989) The Organization of Hypocrisy. Talk, Decision and Actions in Organizations (Chichester: Wiley).

Christensen, T. \& Lægreid, P. (2007) The Whole-of-government Approach to Public Sector Reform, Public Administration Review, 67(6), pp. 1059-1066.

Dent, M. (2005) Post-New Public Management in Public Sector Hospitals? The UK, Germany and Italy, Policy and Politics, 33(4), pp. pp. 623-636. 
DiMaggio, P. \& Powell, W. W. (1991) The Iron Cage Revisited: Institutional Isomorphism and Collective Rationality in Organizational Fields, In: Powell, W. \& DiMaggio, P. (eds.) The New Institionalism in Organizational Analysis (Chicago: University of Chicago Press), pp. 63-82.

Dowding, K. (1994) The Compatibility of Behaviouralism, Rational Choice and "New Institutionalism, Journal of Theoretical Politics, 6(1), pp. 105-117.

Drechsler, W. (2005) The Re-Emergence of 'Weberian' Public Administration after the Fall of New Public Management: The Central and Eastern European Perspective, Halduskultuur, 6, pp. 94-108.

Dunleavy, P., Margetts, H., Bastow, S. \& Tinkler, J. (2005) New Public Management Is Dead - Long Live Digital-Era Governance, Journal of Public Administration Research and Theory, 6, pp. 467-494.

Giauque, D. (2013) Die schweizerische Bundesverwaltung im internationalen Vergleich: auf der Suche nach einer Verwaltungstradition, In: Ladner, A., Chappelet, J.-L., Emery, Y., Knoepfel, P., Mader, L., Soguel, N. \& Varone, F. (eds.) Handbuch der öffentlichen Verwaltung in der Schweiz (Zürich: NZZ libro), pp.47-60.

Goldfinch, S. \& Wallis, J. (2010) Two Myths of Convergence in Public Management Reform, Public Administration, 88(4), pp. 1099-1115.

Hablützel, P., Haldemann, T., Schedler, K. \& Schwaar, K. (eds.) (1995) Umbruch in Politik und Verwaltung. Ansichten und Erfahrungen zum New Public Management in der Schweiz (Bern, Stuttgart, Wien).

Haldemann, T. \& Schedler, K. (1995) New Public Management-Reformen in der Schweiz Aktuelle Projektübersicht und erster Vergleich, In: Hablützel, P., Haldemann, T., Schedler, K. \& Schwaar, K. (eds.) Umbruch in Politik und Verwaltun (Bern, Stuttgart, Wien: Haupt), pp. 99-127.

Hall, P. A. \& Rosemary C., Taylor, R. (1996) Political Science and the Three New Institutionalism, Political Studies, 44(5), pp. 936-957.

Heimgartner, M. \& Dietrich, A. (2008) Wirkungsorientierte Verwaltungsführung in den Schweizer Kantonen. Gegenwärtiger Stand; Eidgenössische Finanzverwaltung (Bern).

Hood, C. (1991) A Public Management for All Seasons?, Pubic Administration, 69(1), pp. 3-19.

Jann, W. (2001) Verwaltungsreformen als Verwaltungspolitik. Verwaltungsmodernisierung und Policy-Forschung, In: Schröter, E. (ed) Empirische Policy- und Verwaltungsforschung (Opladen: Leske + Budrich), pp. 321-344.

Jann, W. (2002) Der Wandel verwaltungspolitischer Leitbilder: Von Management zu Governance?, In: König, K. (ed) Deutsche Verwaltung an der Wende zum 21. Jahrhundert (Baden-Baden), pp. 279-303.

Kersting, N. \&Vetter, A. (eds.) (2003) Reforming Local Government in Europe (Opladen: Leske + Budrich).

Kuhlmann, S. (2009) Politik- und Verwaltungsreform in Kontinentaleuropa. Subnationaler Institutionenwandel im deutsch-französischen Vergleich. Habilitationsschrift an der Universität Potsdam (Baden-Baden: Universität Potsdam).

Kuhlmann, S. \& Wollmann, H. (2013) Verwaltung und Verwaltungsreformen in Europa. Einführung in die vergleichende Verwaltungswissenschaft (Wiesbaden: Springer).

Kuhlmann, S. \& Wollmann, H. (2014) Introduction to Comparative Public Administration. Administrative Systems and Reforms in Europe (Cheltenham: Edward Elgar).

Kuhlmann, S., Bogumil, J. \& Grohs, S. (2008) Evaluating administrative modernization in German local governments: success or failure of the «New Steering Model»?, Public Administration Review, 68(5), pp. 851-863. 
Ladner, A. (2001) Gemeindereformen in der Schweiz - Strategien, Gemeinsamkeiten und Auslöser, Schweizerische Zeitschrift für politische Wissenschaft, 7(3), pp. 1-23.

Ladner, A. (2005) NPM und die Gemeinden, In: Lienhard, A., Ritz, A., Steiner, R. \& Ladner, A. (2005) 10 Jahre New Public Management in der Schweiz - Bilanz, Irrtümer und Erfolgsfaktoren (Bern/Stuttgart/Wien).

Ladner, A. (2009) Auslöser, Ziele und Auswirkungen von kommunalen Reformprojekten, In: Knoepfel, P. (ed) Réformes de politiques institutionnelles et action publique (Bern: Haupt), pp. 51-74.

Ladner, A. (2011) Die wichtigsten institutionellen Reformen zwischen 1970 und 2010 in Bund, Kantonen und Gemeinden: Welche Rolle spielt die konjunkturelle Lage?, In: Soguel, N. (ed) Des politiques au chevet de la conjoncture (Lausanne: Presses polytechniques universitaires romandes), pp.149-174.

Ladner, A. (2013) Der Schweizer Staat, politisches System und Aufgabenerbringung, In: Ladner, A, Chappelet, J.-L., Emery, Y., Knoepfel, P., Mader, L., Soguel, N. \& Varone, F. (eds.) (2013) Handbuch der öffentlichen Verwaltung in der Schweiz (Zürich: NZZ libro), pp. 23-46.

Ladner, A., Cemerin, M., Ritz, A. \& Sager, F. (2007) Evaluation der Parlaments- und Verwaltungsreform Neue Stadtverwaltung Bern NSB. KPM-Schriftenreihe Nr. 18 (Bern: KPM-Verlag).

Lienhard, A., Ritz, A., Steiner, R. \& Ladner, A. (2005) 10 Jahre New Public Management in der Schweiz - Bilanz, Irrtümer und Erfolgsfaktoren (Bern/Stuttgart/Wien).

Lynn Jr., L. E. (2005) Public Management: A Concise History of the Field, In: Ferlie, E., Lynn Jr., L. E. \& Pollitt, C. (eds) The Oxford Handbook of Public Management (Oxford: Oxford University Press).

March, J. G. \& Olsen, J. P. (1984) The New Institutionalism: Organizational Factors in the Political Life, American Political Science Review, 78(3), pp. 734-749.

Mayntz, R. \& Scharpf, F. W. (eds) (1995) Gesellschaftliche Selbstregulierung und politische Steuerung (Frankfurt a. M.: Campus Verlag).

Osborne, D. \& Gaebler, T. (1992) Reinventing Government: How the Entrepreneurial Spirit Is Transforming the Public Sector (Reading, MA: Addison-Wesley).

Ostrom, E., Gardner, R. \& Walker, J. (1994) Rules, Games, and Common-pool Resources (Ann Arbor, MI: University of Michigan Press).

Peters, B. G. (1999) Institutional Theory in Political Science. The 'New Institutionalism' (London \& New York: Continuum).

Pierson, P. (2000) Increasing Returns, Path Dependency, and the Study of Politics, American Political Science Review, 94(2), pp. 251-267.

Pollit, C. \& Geert, B. (2004) Public Management Reform. A Comparative Analysis. 2nd ed. (Oxford: Oxford University Press).

Reichard, C. (1994) Umdenken im Rathaus. Neue Steuerungsmodelle in der deutschen Kommunalverwaltung (Berlin: Edition Sigma).

Rieder, S. \& Lehmann, L. (2002) Evaluation of New Public Management Reforms in Switzerland. IPMR, 3(2), pp. 25-43.

Rieder, S. \& Widmer, T. (2007) Kantone im Wandel. Reformaktivitäten der Schweizer Kantone zwischen 1990 und 1999 (Bern/Stuttgart/Wien).

Ritz, A. (2003) Evaluation von New Public Management. Grundlagen und empirische Ergebnisse der Bewertung von Verwaltungsreformen in der schweizerischen Bundesverwaltung (Bern/Stuttgart/Wien). 
Schedler, K. (1995) Ansätze einer wirkungsorientierten Verwaltungsführung. Von der Idee des New Public Management (NPM) zum konkreten Gestaltungsmodell. Fallbeispiel Schweiz (Bern/Stuttgart/Wien: Paul Haupt).

Schedler, K. \& Proeller, I. (2003) New Public Management (Bern: Paul Haupt).

Steiner, R. (2000) New Public Management in Swiss municipalities, International Public Management Journal, 3(2), pp. 169-189.

Steinmo, S. \& Thelen, K. (eds) Structuring Politics: Historical Institutionalism in Comparative Analysis (New York: Cambridge University Press).

Steiner, R., Ladner, A., Lienhard, A., Rieder, L. \& Mérillat, L. (2006) Zwischenevaluation des Reformprojekts PRIMA in Riehen (BS), KPM-Schriftenreihe Nr. 8 (Bern: KPMVerlag).

Thelen, K. \& Steinmo, S. (1992) Historical Institutionalism in Comparative Politics, In: Steinmo, S., Thelen, K. \& Longstreth,, F., (eds.) Structuring Politics: Historical Institutionalism in Comparative Analysis (Cambridge: Cambridge University Press), pp. $1-32$.

Tsebelis, G. (2002) Veto Players. How Political Institutions Work (Princeton, NJ: Princeton University Press).

Wollmann, H. (2000) Evaluierung und Evaluierungsforschung von Verwaltungspolitik und -modernisierung - zwischen Analysepotential und -defizit, In: Stockmann, R. (ed.). Evaluationsforschung (Opladen: Leske + Budrich), pp. 195-233. 